\title{
Role of Village Chairman in Implementing Village Fund Policies (Study in Hamalau Village of Sungai Raya, Hulu Sungai Selatan District)
}

\author{
Miftahul Ulum*, Andi Tenri Sompa, Ahmad Yunani
}

Masters in Development Administration, Postgraduate Program, Lambung Mangkurat University, Banjarmasin, Indonesia

DOI: $10.36348 /$ sijlcj.2021.v04i02.014 $\quad$ | Received: 08.02.2021 | Accepted: 20.02 .2021 | Published: 26.02 .2021

*Corresponding author: Miftahul Ulum

\section{Abstract}

The purpose of this study was to analyze and describe the implementation of village fund policies in Hamalau, Sungai Raya District, and Hulu Sungai Selatan Regency. The research method used in this research is a qualitative descriptive method. Sources of data in this study are primary data and secondary data. The informants in this study were the Sungai Raya subdistrict government, the Hamalau village government, and the Hamalau village community leaders. Data collection techniques used in this study was direct observation, interviews, and documentation. The research instruments used in this study were interview guidelines and documentation guidelines. Data collection methods in this research are transect walks, interviews with several informants, and supporting documents which include village development planning documents and reports on the realization of the use of village budgets. The location of this research is in Hamalau Village, Sungai Raya District, Hulu Sungai Selatan Regency. The results showed that the realization of village funds for the 2016 fiscal year was still in the low category. That is the impact of the less than the optimal implementation of the development project due to the unsatisfactory performance of the Hamalau village head in implementing development with his instructional leadership style.

Keywords: Village Fund, Role of Village Head, Project Management, and Hamalau Village.

Copyright $\odot 2021$ The Author(s): This is an open-access article distributed under the terms of the Creative Commons Attribution 4.0 International License (CC BY-NC 4.0) which permits unrestricted use, distribution, and reproduction in any medium for non-commercial use provided the original author and source are credited.

\section{INTRODUCTION}

Law Number 6 of 2014 concerning villages makes villages not only as objects of development but also as subjects of development. The government policy in disbursing the village fund budget aims to encourage progress and equitable development in the village. Village development aims to improve the welfare of rural communities and the quality of human life as well as poverty alleviation through the fulfillment of basic needs, development of village facilities and infrastructure, development of local economic potential, and sustainable use of natural resources and the environment. In essence, village development is all forms of human activity (community and government) in the village in developing themselves, families, communities, and the environment in the village area, whether physical, economic, social, cultural, political, order, defense and security, religion and government. which is carried out in a planned manner and has a positive impact on village progress [1]. Village development consists of two main elements, namely society, and government, which together carry out their respective roles in the implementation of village development.

Village funds are funds sourced from the state revenue and expenditure budget (APBN) allocated to villages which are transferred through the Regency / City Regional Revenue and Expenditure Budget (APBD) and used to finance the implementation of development and empowerment of rural communities. In 2016 Hulu Sungai Selatan District received village funds amounting to Rp. 87,363,772,000.00. The Village Fund is allocated to all villages in Hulu Sungai Selatan Regency and will be distributed to each village with the amount of the budget as regulated by Regent Regulation Number 71 of 2015 concerning procedures for distributing and determining the details of village funds for each village in Hulu Sungai Selatan Regency for the 2016 Fiscal Year. The implementation of village governance in Hulu Sungai Selatan Regency is regulated in Regent Regulation Number 67 of 2015 concerning a list of village authorities based on origin rights and Village-scale local authority in Hulu Sungai Selatan Regency. The authority possessed by the village 
Miftahul Ulum et al., Sch Int J Law Crime Justice, Feb, 2021; 4(2): 121-124

government includes 1) basic village services, 2) village facilities and infrastructure, 3) village local economic development and 4) utilization of natural resources in the village environment.

Sungai Raya District is one of the sub-districts in the Hulu Sungai Selatan Regency which consists of eighteen villages. All villages in the Sungai Raya subdistrict have received village funds which have been channeled into their respective village accounts. Most of the villages in Sungai Raya District have absorbed and used their village budget properly, except for Hamalau village which had the lowest absorption of village funds compared to other villages in Sungai Raya District, which was only around $52.17 \%$. So that infrastructure development activities or community empowerment activities sourced from village funds are still few being realized? The results of development activities which should be useful in people's lives cannot be felt. A leader is required to be able to solve problems and make important decisions regarding the lives of its members. Gordon [2] states that an effective leader is a leader whose group members feel that their needs are met and the leader himself feels that his needs are also being satisfied. The village head as the leader is responsible for implementing the village project. Several things that affect the abilities of the village head include the level of education, the experience of the village head, and age at the time of selection. The study of the role of the village head in implementing village fund policies in Hamalau Village, Sungai Raya District, Hulu Sungai Selatan Regency is needed to find out how the implementation of the village fund policy carried out by the village head of Hamalau and what are the obstacles in implementing the village fund policy in Hamalau Village, Sungai Raya District. Therefore, researchers are interested in researching the role of the head of Hamalau village with the research title "the role of the village head in the implementation of village fund policies (study in Hamalau Village, Sungai Raya District, Hulu Sungai Selatan Regency)".

\section{RESEARCH METHODS}

This study aims to present an overview of the implementation of the village fund program starting from the planning stage, the implementation stage to the activity evaluation stage. The research method used in this research is the descriptive qualitative method. The data sources in this study are primary data and secondary data. Primary data is data obtained by researchers directly from informants at the research location. Meanwhile, secondary data is data obtained from various scientific libraries and documents obtained from related agencies that support this research. The informants in this study were the Sungai Raya subdistrict government, the Hamalau village government, and the Hamalau village community leaders. Data collection techniques used in this study was direct observation, interviews, and documentation.
The research instruments used in this study were interview guidelines and documentation guidelines. Data analysis in this study used the Participatory Rural Appraisal (PRA) technique. Chambers [3] states that PRA is an approach that allows village communities to share information, improve and analyze knowledge about village conditions and life, and involve the community in making and implementing plans. Several methods of data collection in PRA include transect walks, interviews, and documentation. This research was conducted in Hamalau Village, Sungai Raya District, Hulu Sungai Selatan Regency.

\section{RESULTS AND DISCUSSION}

The success of an activity is greatly influenced by the factors of how a plan is prepared. Good planning is never separated from the role of a leader in an organization. The leader of the organization in the village government is the village head. The Hamalau Village Head, who plays the role of the person in charge of implementing development activities projects in Hamalau Village, has carried out the stages of compiling village development planning documents as stipulated in Law Number 6 of 2014 concerning villages and their implementing regulations. This was reinforced by the Sungai Raya District Government which said that the formulation of a village development planning document in Sungai Raya District had gone through the stages according to the applicable provisions including Hamalau village.

The village head of Hamalau stipulates the RKPdesa document like an annual plan through village meetings. The implementation of village development planning deliberations (Musrenbang) is intended to absorb community aspirations in the form of proposals for activities to be implemented in the village. Based on the results of the research, it shows that Hamalau Village has organized a Hamalau Village Musrenbang which involves the layers of the village community to submit proposed activity plans to the Hamalau Village Government. All proposals submitted by the community were recorded and contained in the Hamalau Village RKP document. The proposals that have been accommodated by the Hamalau Village Government will later become material for consideration in determining the direction of development policy in Hamalau Village. Through the description of how the village development planning process is described above, it can be concluded that the Hamalau village head plays a very important role in the formulation of village development planning documents according to the planning stages that must be followed according to applicable regulations.

After the stipulation of the APB Desa document, the village government needs to formulate an activity project implementation agenda to determine when the planned activities will start, be postponed, and complete 
Miftahul Ulum et al., Sch Int J Law Crime Justice, Feb, 2021; 4(2): 121-124

so that the implementation of activities will run effectively. However, the research results show that the village head of Hamalau has not prepared a schedule for the implementation of activities as it should be. This is because it is not known that in the implementation of activities in the village it is necessary to arrange an implementation schedule. So that the implementation of activities so far has only followed community requests which are urgent with the availability of a budget in the village treasury account. The problems that are always faced by various parties in the implementation of village activities are natural factors, whether in the form of seasons being faced, natural disasters that occur, or other natural conditions that will affect the implementation of an activity. Moreover, physical development activities are highly dependent on natural factors at hand. Therefore, the preparation of an activity schedule also affects the realization of the implementation of activities in the village. Hamalau Village Head confirmed the importance of preparing an activity agenda in the future to improve the implementation of development in Hamalau Village.

The village head is the highest policymaker in the village government. Through the policies taken by the village head, an activity carried out can be controlled following the situation and conditions faced which will affect the outcome of an activity project in the village. Based on reports on the use of village funds in 2016 the implementation of project activities in Hamalau Village was not optimal. Some of the project activities cannot be realized by the Hamalau Village Government. This is because the Hamalau Village Government officials have not been able to show the accountability document for the use of village funds in 2015. So that the village funds for the first phase of the 2016 fiscal year that is already in the Hamalau Village cash account cannot be disbursed until the accountability document for the use of the Hamalau Village Fund can be fulfilled. This has an impact on delays in the disbursement of village funds by the Hamalau village government which was only implemented in August 2016. This certainly has an impact on the implementation of project activities in 2016, where the conditions of the Hamalau village government apparatus as executors of project activities are very limited. So that the division of tasks feels heavier, especially in fulfilling accountability documents and administrative documents as evidence of budget use. The lack of maximum personnel implementing project activities, both in terms of quality and quantity, certainly affects the implementation of project activities in the village. Hamalau village head in implementing project activities is only assisted by one head of government affairs as well as concurrently acting as the village secretary (plt) and one person as head of development affairs. Meanwhile, in terms of the quality of human resources, the village government apparatus Hamalau relies more on the role of Plt. Village secretary who has a Bachelor's education background. Another obstacle faced by the Hamalau Village government in implementing development project activities in the village is the weather factor that is not supportive in the process of implementing village development activities such as road construction in RT 04 which is experiencing a swelling of funds to complete projects amid difficult terrain. This certainly has an impact on other development activities in Hamalau Village were part of the budget has been used to complete the project. Besides, the budget swelling in these project activities caused the preparation of reports and supporting administrative documents to experience difficulties in fulfilling them. This certainly took a lot of time and thought for Hamalau village officials to assist the village head in fulfilling the activity accountability documents. Until the end of the 2016 fiscal year, the village government of Hamalau has not been able to fulfill the accountability document for the use of village funds sourced from village funds phase one in the remaining time available. This resulted in disapproval of the withdrawal of phase two of village funds for development activities that had not yet been carried out. The problems faced by the Hamalau Village Government are inseparable from the role of the Hamalau Village Head in controlling the course of development activities in the village.

The Sungai Raya Subdistrict Government seeks to provide guidance and knowledge on the duties and functions as well as the role of village officials in governance, development, and community services. This was done so that village officials could carry out their assigned tasks better. This was also done by the ranks of the PMD Office of Hulu Sungai Selatan Regency which collaborated with various parties to carry out technical guidance and training for village officials. The implementation of development carried out by the Hamalau Village Government in 2019 has made significant progress when compared to the implementation of development in 2016. Almost all project activities planned in 2019 can be realized by the Hamalau Village Government. This of course affects better village budget absorption. So that with the implementation of development in Hamalau Village better, the people of Hamalau Village can also benefit from the results of the development projects being implemented.

The success of a village development project cannot be separated from the support of the village community itself to take part in the implementation of development in their village. Especially the village community organizations (LKD), some of whose members are the activity management team (TPK) in the village. Community involvement will make work easier to carry out. The village head's policy of empowering existing village officials to help carry out project activities in his village resulted in passive community involvement in village development projects. This is in line with the opinion expressed by 
Miftahul Ulum et al., Sch Int J Law Crime Justice, Feb, 2021; 4(2): 121-124

the Sungai Raya District Government and Hamalau village community leaders that the policies taken by the village head in controlling development activities in Hamalau village do not involve elements of the village community. The Hamalau Village Head's consideration by not involving the TPK was a doubt about the community's ability to assist in the implementation of activities, especially in fulfilling the accountability documents and reports required regarding the implementation of project activities. Meanwhile, physical work in the field has used the services of masons/workers in Hamalau Village. The village head in carrying out his role is influenced by personal factors from the village head himself such as the level of education, experience, and leadership style that exists in the village head. Hamalau Village Head who has a high school education background is considered to have sufficient insight. As for the aspect of working experience in government institutions, the Hamalau Village Head has served as the village head for two terms of office. So that the abilities of the Hamalau Village Head are better than the Village Head who has only been elected once and has served as the village head. The leadership style of the Hamalau village head is instructional. This was motivated by the behavior of the Hamalau Village Head who gave more direction to village officials and did not involve elements of his village community [4].

There are several obstacles faced in implementing village funds, namely, first, the village head does not understand the principles of village financial management, namely the principle of transparency. This was marked by the implementation of development activities projects carried out by his party without involving the Hamalau Village TPK. Second, the village head does not have good time management. This can be seen from the delay of the village head in fulfilling the accountability report for the use of the Village Fund and its supporting administrative documents as recommended by the BPK RI. Third, Hamalau village heads are constrained in distributing tasks to existing village officials, where the quality and quantity of village officials owned is not optimal.

\section{CONCLUSSION}

Based on the results of the study, it can be concluded that the low realization of village funds for the 2016 fiscal year is the impact of the implementation of development activities projects in Hamalau Village that cannot be implemented optimally. The role of the Hamalau village head is quite good at the planning stage as stipulated in the applicable laws. Although at the stage of setting the village development project agenda, the village government has not been able to compile a schedule for implementing activities. Besides, the role of the village head in controlling development projects is also less than optimal. This can be seen from the development activities that were planned for 2016 not being maximally realized. The leadership style of the Hamalau village head is an instructional leadership style. This can be seen from the behavior of the Hamalau village head, which provides more direction to village officials and does not involve elements of his village community. There are several obstacles in the implementation of village funds, namely the lack of understanding of the principle of transparency in village financial management, inequality in distributing the existing village apparatus tasks, and the less than optimal quality and quantity of village officials.

\section{REFERENCES}

1. Ronny, S. (2016). EJurnal Ilmu Administrasi Negara.02-09-16. ejournal.an.fisip-unmu.ac.id

2. Gordon, T. (1994). Kepemimpinan yang Efektif. Jakarta: Raja Grafindo Persada

3. Chambers, R. (1992). PRA-Participatory Rural Appraisal-Memahami Desa Secara Partisipatif .Yogyakarta: Kanisius.

4. Thoha, M. (1988). Kepemimpinan dalam Manajemen-Suatu Pendekatan Perilaku. Jakarta: Rajawali 